\title{
"BioProzessTrainer" as training tool for design of experiments
}

\author{
Ralf Pörtner ${ }^{1 *}$, Oscar Platas-Barradas', Janosh Gradkowski ${ }^{1}$, Richa Gautam ${ }^{1}$, Florian Kuhnen², Volker C Hass ${ }^{2}$ \\ From 22nd European Society for Animal Cell Technology (ESACT) Meeting on Cell Based Technologies \\ Vienna, Austria. 15-18 May 2011
}

\section{Concept}

Design and optimization of cell culture processes requires intensive studies based on "Design of experiments"-strategies. In academia teaching of DoE-concepts is often insufficient, as in most cases only simple culture strategies (batch) can be performed, as time and money are limited. More complex tasks such as feeding strategies for fed batch culture can be discussed theoretically only.

To close this gap the virtual "BioProzessTrainer", a model based simulation tool, was developed. It supports biotechnological education with respect to process strategies, bioreactor control, kinetic analysis of experimental data and modeling. Along with a set of examples for different control and process strategies (batch, fed batch, chemostat etc.) learners are prepared for real experiments $[1,2]$.

The "BioProzessTrainer" (Figure 1) helps to improve the quality of education by using interactive learning forms and by transmitting additional knowledge and skills. Costs for practical experiments can be minimized by reducing plant operation costs. Here a concept for teaching DoE-concepts for batch- (optimization of e.g. substrate concentrations and inoculation cell density) and fed-batch-processes (evaluation and optimization of feeding strategy) using the "BioProzessTrainer" is shown.

\section{Example 1}

DoE for impact of glucose and glutamine concentration during batch $(1,5 \mathrm{~L})$ on cell density and antibody concentration of a mammalian cell line

Experimental design:

$>$ Seed concentration: 4E8 cells/L $[ \pm 10 \%]$ $\gg$ Glucose conc.: low $15 \mathrm{mmol} / \mathrm{L}$; high $30 \mathrm{mmol} / \mathrm{L}$

$>$ Glutamine conc.: low $1 \mathrm{mmol} / \mathrm{L}$; high $4 \mathrm{mmol} / \mathrm{L}$

$>$ Culture time: $24 \mathrm{~h}$

To induce an experimental error, the seed concentration was varied by $+-10 \%$. Results see Table 1

Analysis via statistical tools:

$>$ One-dimensional ANOVA with respect to glucose at high glutamine concentrations: glucose conc. not significant for cell conc. $(\mathrm{p}=0.1)$, significant for antibody conc. ( $\mathrm{p}=0.044)$; level of significance 0.05

$>$ Two-dimensional ANOVA with repetition: interaction between glucose and glutamine conc. not significant for cell conc. $(\mathrm{p}=0.14)$; significant for antibody conc. $(\mathrm{p}=0.046)$; level of significance 0.05

\section{Example 2}

DoE for impact of feed rate for glucose and glutamine feed during fed batch (constant feed rate) on cell density and antibody concentration of a mammalian cell line

Experimental design:

$>$ Seed concentration: 8 E8 cells/L

$>$ Glucose conc. in glucose feed: $180 \mathrm{mmol} / \mathrm{L}$

$>$ Glutamine conc. in glutamine feed: $30 \mathrm{mmol} / \mathrm{L}$

$>$ Start feed: $24 \mathrm{~h}$; start volume $1.5 \mathrm{~L}$; final volume $3 \mathrm{~L}$

$>$ Feed rate glucose / glutamine feed: low $0.02 \mathrm{~mL} / \mathrm{min}$; high $0.08 \mathrm{~mL} / \mathrm{min}$

Results see Table 2

Analysis via statistical tools:

$>$ Two-dimensional ANOVA without repetition: glucose feed rate not significant for cell conc. $(\mathrm{p}=0.295)$ and antibody conc. $(\mathrm{p}=0.699)$; glutamine feed rate significant for cell conc. $(\mathrm{p}=0.035)$ and not for antibody conc. $(\mathrm{p}=0.653)$; level of significance 0.05

\footnotetext{
* Correspondence: poertner@tuhh.de

1 Institute of Bioprocess and Biosystems Engineering, Hamburg University of Technology Hamburg, D-21073, Germany

Full list of author information is available at the end of the article
}

(c) 2011 Pörtner et al; licensee BioMed Central Ltd. This is an open access article distributed under the terms of the Creative Commons Attribution License (http://creativecommons.org/licenses/by/2.0), which permits unrestricted use, distribution, and reproduction in any medium, provided the original work is properly cited. 


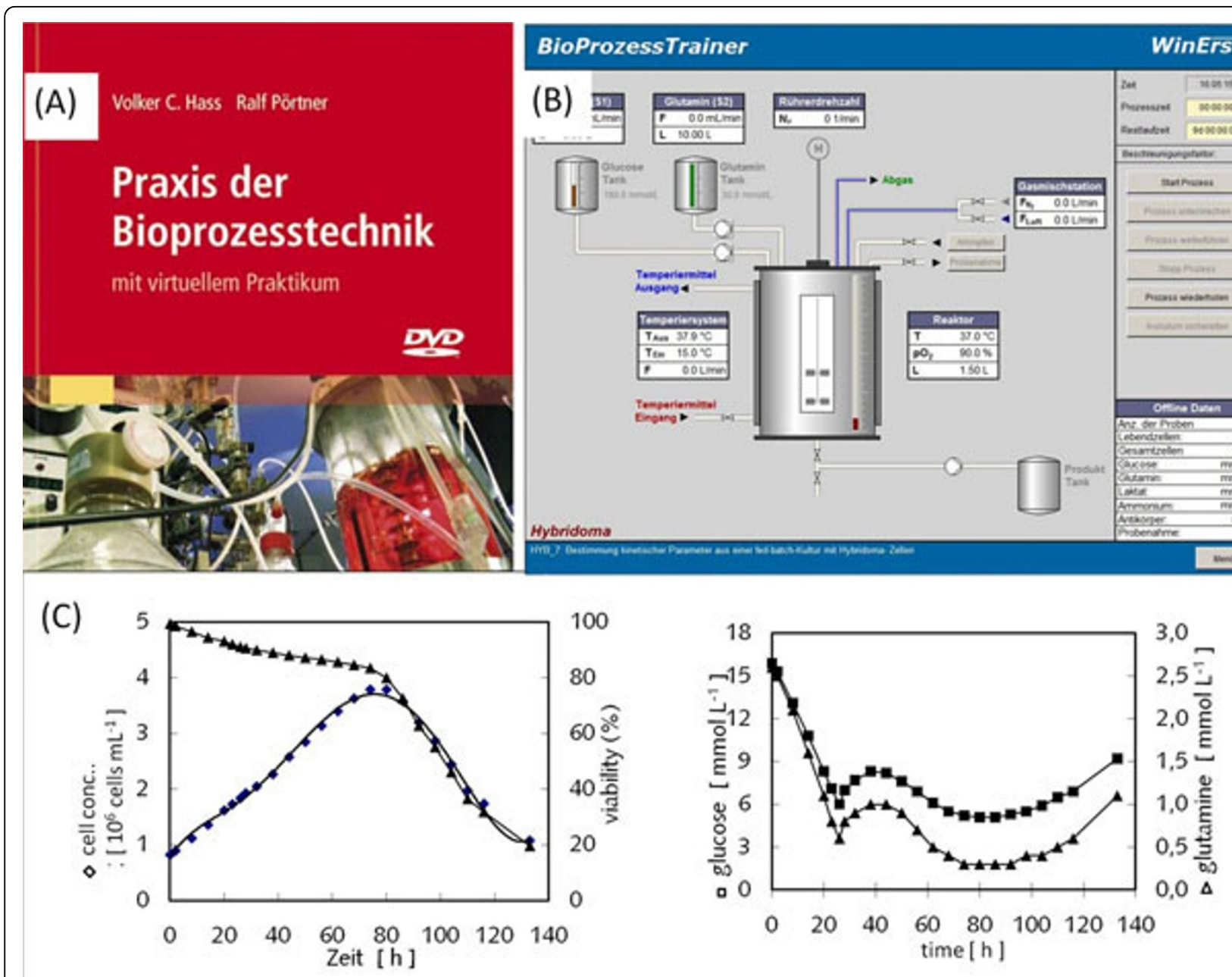

Figure 1 (A) Teaching material: theoretical back-ground, exercises, sample solution [1] (B) Screen of „BioProzessTrainer“ (C) Example: fed-batch process with fixed feed rate perfomed with the BioProzessTrainer

Table 1 DoE performed with the BioProzessTrainer

\begin{tabular}{|c|c|c|c|c|c|c|}
\hline \multirow{2}{*}{\multicolumn{2}{|c|}{ seed conc. $\left[10^{8}\right.$ cells/L ] }} & \multirow{3}{*}{ glutamine $[\mathrm{mmol} / \mathrm{L}]$} & \multicolumn{2}{|c|}{ cell conc. $\left[10^{8}\right.$ cells/L] } & \multicolumn{2}{|c|}{ antibody conc. [mg/L] } \\
\hline & & & \multicolumn{4}{|c|}{ glucose $[\mathrm{mmol} / \mathrm{L}]$} \\
\hline & & & 15 & 30 & 15 & 30 \\
\hline set & 4.0 & 1 & 7.71 & 8.01 & 11.8 & 12.6 \\
\hline$-10 \%$ & 3.6 & 1 & 7.15 & 7.49 & 11.1 & 12.1 \\
\hline$+10 \%$ & 4.4 & 1 & 8.23 & 8.49 & 12.3 & 13.0 \\
\hline set & 4.0 & 4 & 1.17 & 1.37 & 22.5 & 27.7 \\
\hline$-10 \%$ & 3.6 & 4 & 1.06 & 1.24 & 20.6 & 25.2 \\
\hline$+10 \%$ & 4.4 & 4 & 1.27 & 1.49 & 24.4 & 30.2 \\
\hline
\end{tabular}

Impact of glucose and glutamine concentration on cell density and antibody concentration 
Table 2 Impact of feed rate for glucose and glutamine feed during fed-batch (constant feed rate) on cell density and antibody concentration

\begin{tabular}{ccccc}
\hline & \multicolumn{2}{c}{ cell conc. $\left[\mathbf{1 0}^{\mathbf{9}}\right.$ cells/L] } & \multicolumn{2}{c}{ antibody conc. [mg/L] } \\
glutamine feed rate $[\mathrm{mL} / \mathrm{min}]$ & \multicolumn{2}{c}{ glucose feed rate $[\mathrm{mL} / \mathrm{min}]$} & 0.02 & 0.08 \\
\hline 0.02 & 0.02 & 0.08 & 84.2 & 63.0 \\
0.08 & 2.10 & 2.15 & 67.0 & 133 \\
\hline
\end{tabular}

\section{Author details}

'Institute of Bioprocess and Biosystems Engineering, Hamburg University of Technology Hamburg, D-21073, Germany. ${ }^{2}$ Institute of Environmental and

Bio-Technology, Hochschule Bremen, D-28119, Germany.

Published: 22 November 2011

\section{References}

1. Hass V, Pörtner R: Praxis der Bioprozesstechnik. Spektrum Akademischer Verlag;978-3-8274-1795-4 2009.

2. Pörtner R, Hass VC: Interactive virtual learning environment for biotechnology (eLearnBioTec). Chemie-Ingenieur-Technik 2005, 77(8):1256.

doi:10.1186/1753-6561-5-S8-P62

Cite this article as: Pörtner et al:: "BioProzessTrainer" as training tool for design of experiments. BMC Proceedings 2011 5(Suppl 8):P62.

Submit your next manuscript to BioMed Central and take full advantage of:

- Convenient online submission

- Thorough peer review

- No space constraints or color figure charges

- Immediate publication on acceptance

- Inclusion in PubMed, CAS, Scopus and Google Scholar

- Research which is freely available for redistribution

Submit your manuscript at www.biomedcentral.com/submit 